\title{
Spatial Analysis of Livestock Grazing and Forest Service Management in the High Uintas Wilderness, Utah
}

\author{
John Carter $^{1 *}$, Emanuel Vasquez ${ }^{2}$, Allison Jones ${ }^{2}$ \\ ${ }^{1}$ Kiesha's Preserve, Paris, ID, USA \\ ${ }^{2}$ Wild Utah Project, Salt Lake City, UT, USA \\ Email: ^jcoyote23@gmail.com
}

How to cite this paper: Carter, J., Vasquez, E. and Jones, A. (2020) Spatial Analysis of Livestock Grazing and Forest Service Management in the High Uintas Wilderness, Utah. Journal of Geographic Information System, 12, 45-69.

https://doi.org/10.4236/jgis.2020.122003

Received: February 8, 2020

Accepted: March 17, 2020

Published: March 20, 2020

Copyright ( 2020 by author(s) and Scientific Research Publishing Inc. This work is licensed under the Creative Commons Attribution International License (CC BY 4.0).

http://creativecommons.org/licenses/by/4.0/

\begin{abstract}
This case study addresses the Forest Service reauthorization for grazing of domestic sheep in Utah's High Uintas Wilderness, USA. It provides an approach using spatial analysis and aerial imagery to evaluate the lands capable of being grazed based on Forest Service criteria and field surveys. The resulting model and analysis demonstrated that the Forest Service has not applied its own criteria. This has led to the Forest Service overestimating the amount of land and numbers of sheep that can be supported in the study area. Past field studies show this has resulted in environmental damage by grazing sheep. Our analysis concludes that the numbers of domestic sheep should be greatly reduced to protect these lands and wilderness values. Limitations of the study include the lack of a suitably detailed soil survey to determine erosion susceptibility, a lack of ground cover data, a lack of Forest Service data for the level of grazing use, or utilization, and the lack of a Forest Service quantitative measurement of vegetation production in each plant community and soil type. In the end, our use of aerial imagery, GIS determinations of areas of steep slopes and dense forests, and our measurement of vegetation production in the dominant soil types showed most of the land is not capable for grazing domestic sheep even in the absence of this other data.
\end{abstract}

\section{Keywords}

Livestock, Capacity, Wilderness, Spatial Analysis, Remote Sensing

\section{Introduction}

In 2014, the Ashley National Forest (ANF) and the Uinta-Wasatch-Cache National Forest (UWCNF) in Utah initiated a scoping process for the High Uintas 
Wilderness Domestic Sheep Analysis, followed by a Draft Environmental Impact Statement in 2019 [1] [2]. The purpose of the project is to reauthorize grazing of 12,850 ewe/lamb pairs of domestic sheep on ten grazing allotments totaling 160,410 acres within the High Uintas Wilderness which lies in NE Utah's Uinta Mountain Range.

Due to the importance of these watersheds, their associated water supplies for the public, wilderness qualities, and concerns for the effects of this proposal on these values as well as native fish and wildlife, the authors engaged in a study and Geographic Information System (GIS) analysis to inform the Forest Service environmental analysis. The goal of the study was to evaluate the capacity of the allotments to support domestic sheep grazing using Forest Service criteria, field data collection and image analysis combined in a GIS analysis. Using such a technique offers a means of reducing or eliminating many of the negative impacts of livestock grazing by balancing livestock use with available capacity and avoiding placing livestock in sensitive areas such as steep slopes, unstable or highly erodible soils. This can lead to healthier watersheds, reduction of soil erosion, restoration of fish and wildlife habitat and their associated populations across not only wilderness areas, but all livestock-grazed public and private lands.

\subsection{Livestock Grazing Extent, Effects and the Need for a Systematic Approach to Management}

There are approximately 3.4 billion ha worldwide that are grazed by livestock, with $73 \%$ estimated to be suffering soil degradation [3]. In the western USA, livestock are permitted to graze on over 103 million acres within the National Forest System and 168 million acres of public lands managed by the Bureau of Land Management [4], including 13 million acres of designated wilderness [5]. These BLM and Forest Service managed lands suffer degradation with over 50\% in poor or fair condition [6].

Regionally important rivers such as the Bear, Green and Colorado are supplied water from the High Uintas Wilderness area watersheds and provide water to regional populations for agriculture, municipal and industrial use, power and recreation [7]. These rivers and their watersheds are also important to native fish such as Colorado River cutthroat trout (Oncorhynchus clarkii pleuriticus) and Bonneville Cutthroat trout (Oncorhynchus clarki utah). Wildlife, including bighorn sheep (Ovis canadensis), Rocky Mountain elk (Cervus canadensis nelsoni) and many other mammals and birds also depend on these watersheds [2]. The High Uintas Wilderness is a core area for Canada lynx (Lynx canadensis) [8] and historically significant numbers occurred here [9]. It is part of a Regionally Significant Wildlife Corridor (Corridor) connecting the Greater Yellowstone Ecosystem and Northern Rockies to the Uinta Mountains and Southern Rockies. This Corridor is recognized by the Forest Service as well as regional conservation organizations [10] [11] [12]. It is important to maintain habitat integrity and productivity in these watersheds for these purposes, so overstocking of li- 
vestock or grazing livestock in areas susceptible to accelerated erosion and degradation must be avoided.

A meta-analysis of the effects of cattle grazing on arid ecosystems in western North America found reductions in rodent species diversity and richness; vegetation diversity; shrub, forb and grass cover; total vegetation cover and biomass; seedling survival; biological crust cover; and litter cover and biomass while soil bulk density increased, soil erosion increased, and infiltration rates decreased in grazed areas when compared to ungrazed areas [13]. A comprehensive review of ecosystem effects of livestock grazing in western North America found that livestock grazing reduces levels of biodiversity, leads to decreased population densities for a wide variety of taxa, disrupts ecosystem functions, including nutrient cycling and succession, changes community organization, and changes the physical characteristics of both terrestrial and aquatic habitats [4]. A similar review of livestock effects to streams and riparian ecosystems determined that livestock grazing negatively affects water quality and seasonal quantity, stream channel morphology, hydrology, riparian zone soils, instream and streambank vegetation, and aquatic and riparian wildlife. No positive environmental effects of grazing were found in this comprehensive survey of the literature [14].

Field surveys by the Forest Service in the 1960s in the High Uintas Wilderness documented erosion damage on highly erodible soils and steep slopes which had developed gullies, and which was exacerbated by sheep grazing and trampling [15]. Mont Lewis, a Forest Service range conservationist working in the Uinta Mountains in the 1960s, documented accelerated erosion, alpine turf in poor condition, and lakes being filled with sediment from grazing sheep in areas that were sensitive to erosion damage [16].

A recent study using sediment cores from Lake EJOD in a grazing allotment in the High Uintas Wilderness found increased nutrient and sediment loading in the past century, coincident with the period livestock have grazed here. This is a departure from rates of deposition going back 5300 years [17] (Figure 1). Lewis (1970) noted that these non-suitable areas (today these are called non-capable) should not be grazed [16]. Many of the soils were determined to have a very high erosion hazard. Surveys in the late 1990s and early 2000s showed grazed uplands had suffered loss of plant cover with upland grazed areas having bare soil averaging over 50\% while areas that had not been grazed for decades had almost no bare soil. Streams were damaged from high runoff events creating bank scouring (Figure 2) and steep slopes were being grazed and trampled [18] (Figure 3). Surveys by soil scientists working for the Ashley National Forest in the 1980s described severe erosion and loss of soil cover and biological crusts [19]. In recent decades Forest Service monitoring has been sporadic and focused in areas of low erosion hazard in more level terrain such as valleys, wet or mesic meadows, and riparian areas, finding conditions to be satisfactory [2] [15].

This evidence of degradation as a result of grazing livestock at levels exceeding capacity and in areas of high susceptibility to erosion is what the straightforward 


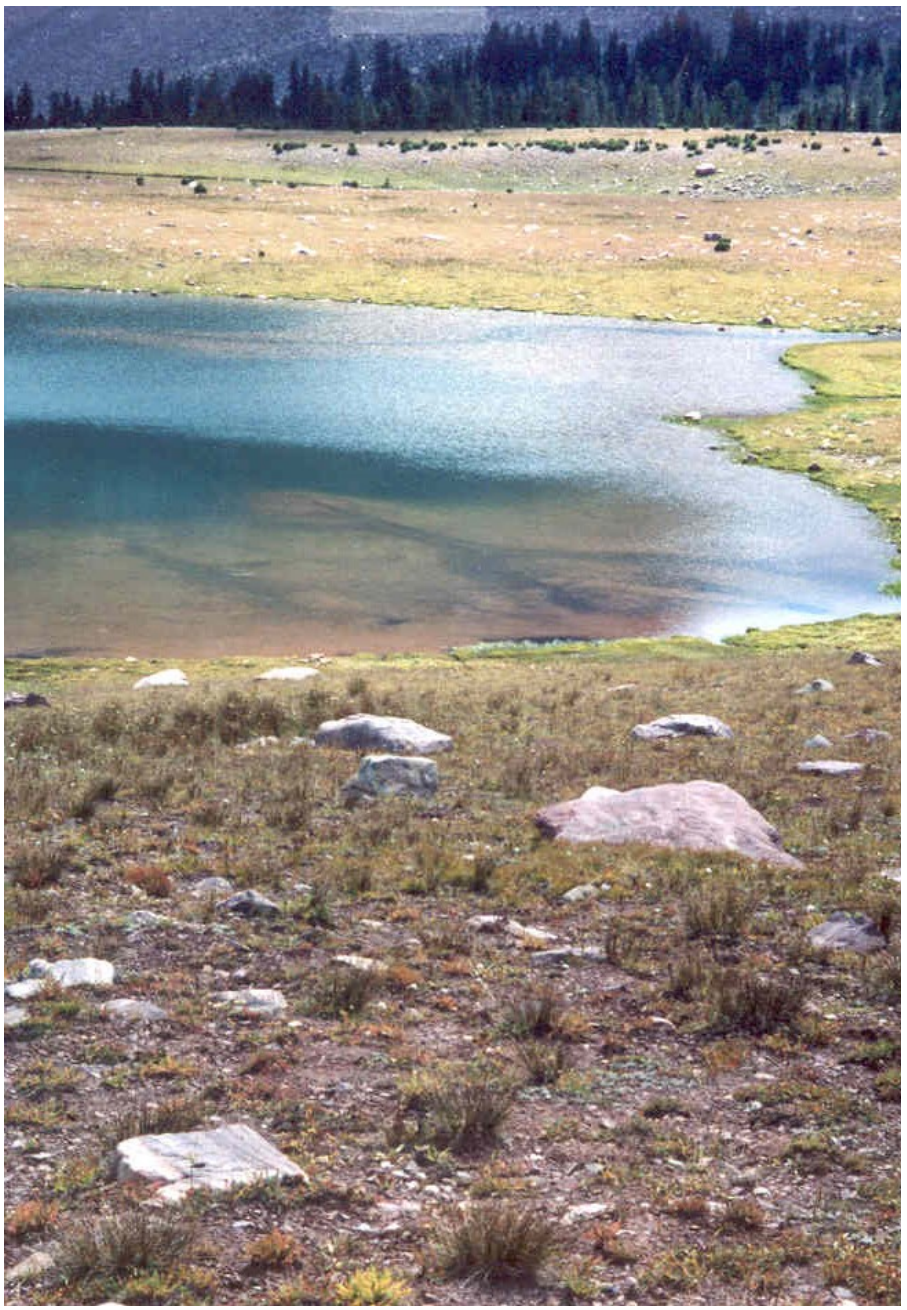

Figure 1. Lake EJOD, High Uintas Wilderness, deposits of sediment entering the lake from its grazed watershed [18].

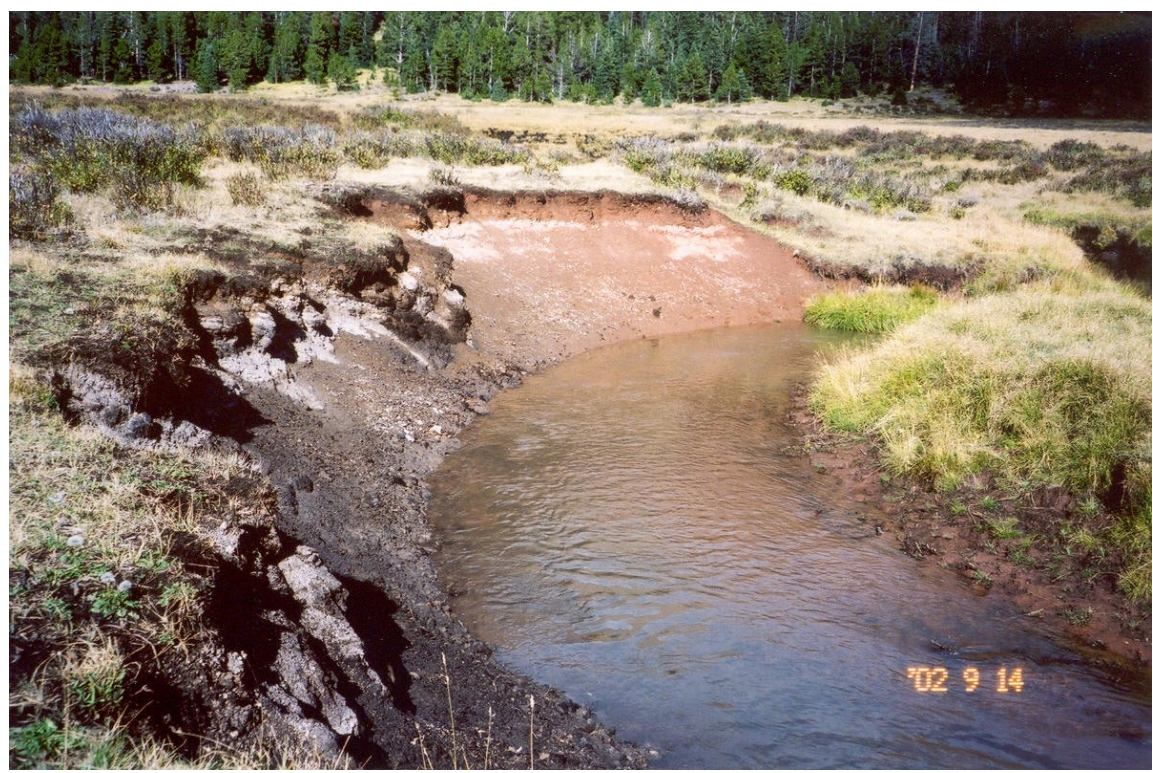

Figure 2. Stream bank scouring, High Uintas Wilderness [18]. 


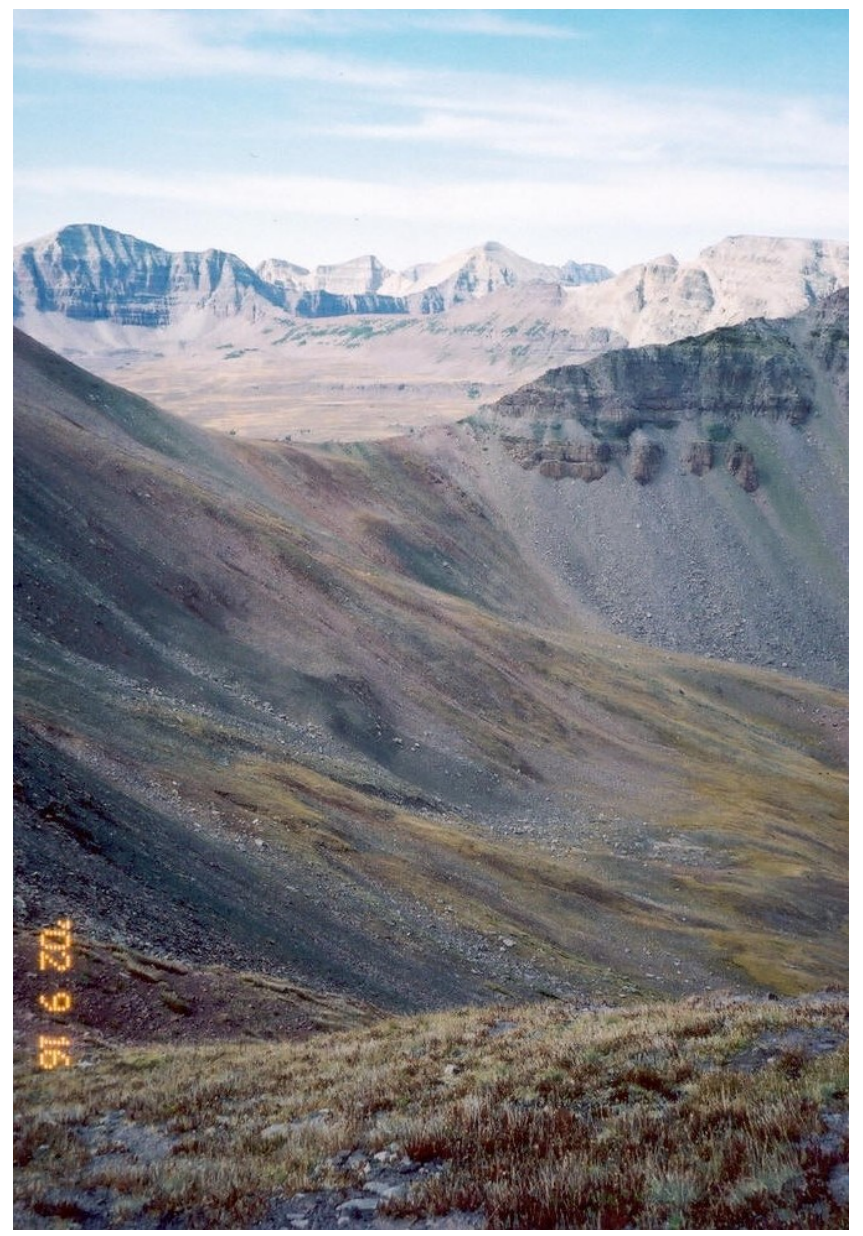

Figure 3. High Uintas Wilderness steep slopes grazed by domestic sheep [18].

use of GIS analysis techniques we provide here, combined with systematic data collection to fill data gaps, could reverse.

\subsection{Grazing in Wilderness}

In 1964, Congress passed the Wilderness Act and defined wilderness: "A wilderness, in contrast with those areas where man and his works dominate the landscape, is hereby recognized as an area where the earth and its community of life are untrammeled by man, where man himself is a visitor who does not remain". Wilderness is "land retaining its primeval character and influence, without permanent improvements or human habitation, which is protected and managed so as to preserve its natural conditions....” In addition, wilderness should be "affected primarily by the forces of nature, with the imprint of man's work substantially unnoticeable" (16 U.S.C. $\$ 1131(\mathrm{c})$ ). The law provided statutory protections for wilderness areas and established the National Wilderness Preservation System. The Act, among other things, mandated that wilderness areas be administered in a manner that will leave them "unimpaired for future use and enjoyment as wilderness" and provide for "the protection of these areas" and "the preservation of their wilderness character" (16 U.S.C. $\$ 1131(\mathrm{a})$ ). 
The provision allowing livestock grazing in the Wilderness Act is an exception to the general premise of the Act, which directs agencies to manage wilderness areas to preserve their wilderness character and natural conditions. "Within wilderness areas in the national forests designated by this Act...the grazing of livestock, where established prior to September 3, 1964, shall be permitted to continue subject to such reasonable regulations as are deemed necessary by the Secretary of Agriculture" (16 U.S.C. $\$ 1133(\mathrm{~d})$ ). Thus, livestock grazing which existed in wilderness areas when the Wilderness Act was enacted, has continued. Livestock grazing is an exception to normal wilderness protections. We have pointed out the various impacts on the land which show the degradation of ecosystem and natural values, which would also be inconsistent with the intent of the Wilderness Act.

\section{Methods}

\subsection{Study Area}

The study area is the ten grazing allotments at issue and their watersheds that occur in the ANF and UWCNF within the High Uintas Wilderness (Figure 4). Allotment boundaries align with watershed divides in most cases. The study area occurs in the Middle Rocky Mountain Physiographic Province [20]. Elevations range from about 8000 feet to 13,528 feet above sea level at the summit of Kings Peak. The land consists of steep canyons, U-shaped glaciated basins and river valleys, alpine tundra, lakes, streams and wetlands, mountain peaks, and large open meadows (Figure 5). Forested areas consist of sagebrush (Artemesia spp.), quaking aspen (Populus tremuloides), lodgepole pine (Pinus contorta), Douglas fir (Pseudotsuga menziesii), subalpine fir (Abies lasiocarpa), and Engelmann spruce (Picea engelmannii) [12] [21].

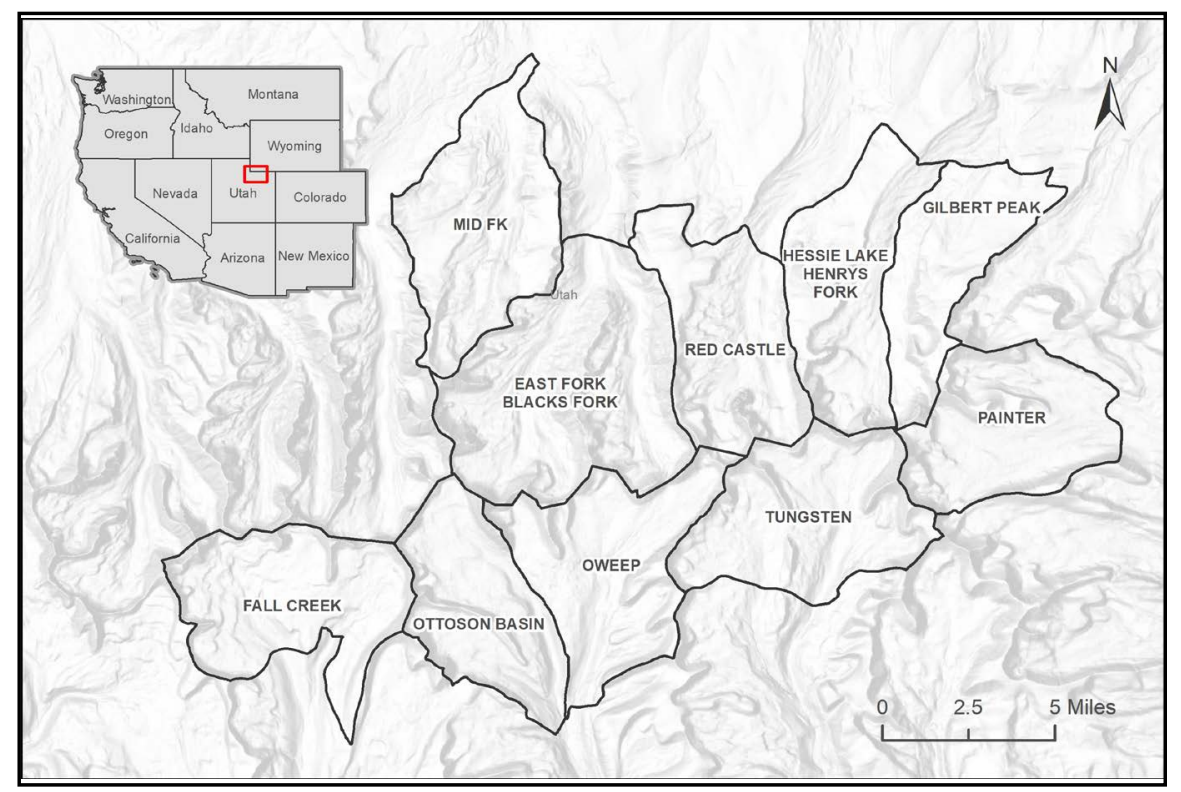

Figure 4. Study location and map of allotments. 


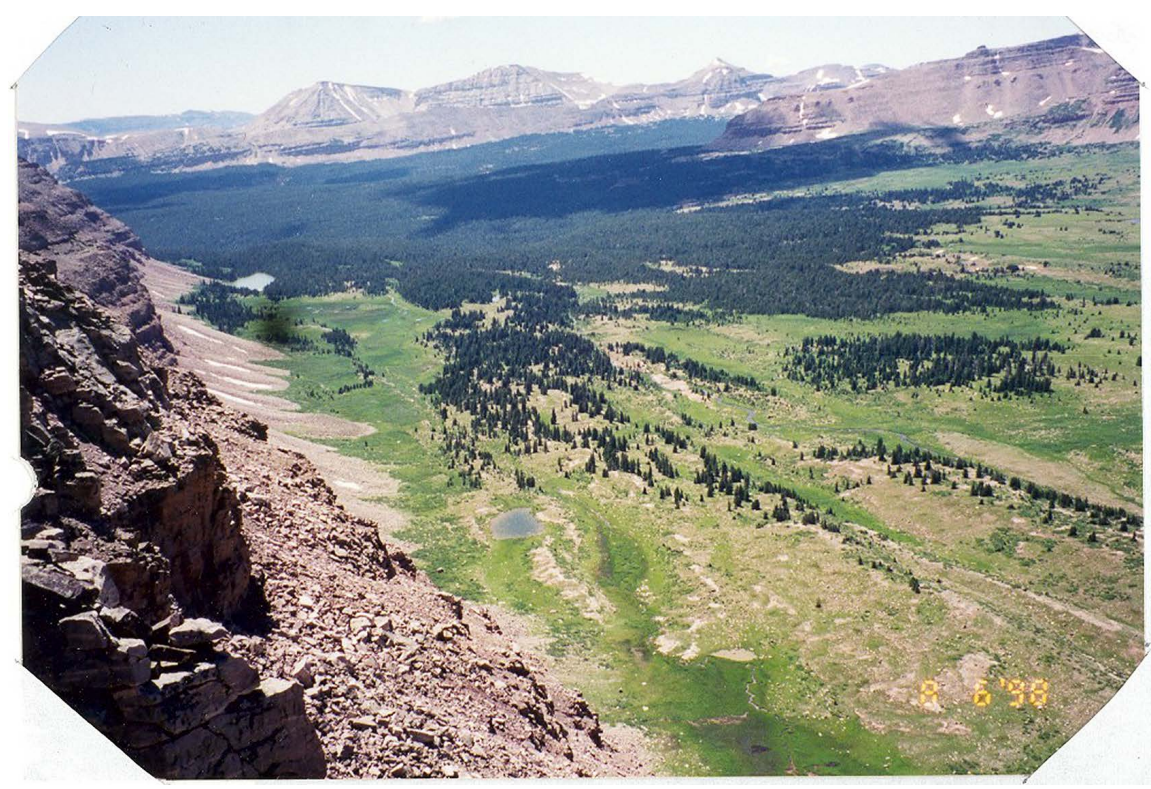

Figure 5. Forest Service photo showing topography, dense forested areas, mixed wetland and upland areas and adjacent steep slopes [15].

The ten grazing allotments cover a total of 160,410 acres and have a near summer-long grazing season [2]. At this high elevation, the grazing season occupies most of the snow-free period with some areas retaining snow into August [15] (Table 1). The Forest Service describes the climate for this alpine area as having annual precipitation between 33 and 50 inches per year with most occurring in the form of snow [16]. Summer thunderstorms are also an important factor [20].

\subsection{Forest Service Capability Criteria}

The concept of "capability" for livestock grazing is a core concept directed at limiting soil erosion and degradation of grazing allotment watersheds and plant communities. It does so by factoring out areas of steeper slopes, highly erodible soils, and barren areas, in order to reduce risk of soil erosion and degradation of plant communities which leads to loss of productivity. It also is used to determine stocking rates based on forage consumption rates of livestock and allocates an appropriate proportion of the available, preferred or desirable forage species on the capable acres to livestock so that stocking rates are sustainable and reduce the risk of degradation [22]. The capable lands and stocking rates on the High Uintas Wilderness allotments have not been updated to reflect more recent guidance from the Region 4 Forest Service that oversees the ANF and UWCNF that manage these ten grazing allotments.

The current USFS regional criteria (Criteria) for range capability were described in a 1998 memorandum by the Forest Service [23]. These were:

1) Areas with less than 45 percent slope for domestic sheep, $30 \%$ for cattle.

2) Areas producing or having the potential to produce an average of $200 \mathrm{lbs}$. or more of forage/acre on an air-dry basis over the planning period. 
Table 1. Numbers of permitted sheep and length of grazing season.

\begin{tabular}{cccc}
\hline Allotment & Permitted Ewe/Lamb Pairs & Season & Allotment Acres \\
\hline East Fork Blacks Fork & 1350 & $7 / 6-9 / 10$ & 25,440 \\
Fall Creek & 1100 & $7 / 1-9 / 30$ & 16,612 \\
Gilbert Peak & 1400 & $7 / 11-9 / 10$ & 11,896 \\
Hessie Lake Henry's Fork & 1400 & $7 / 11-9 / 10$ & 14,539 \\
Middle Fork Black's Fork & 1200 & $7 / 11-9 / 10$ & 16,855 \\
Ottoson Basin & 1300 & $7 / 15-9 / 10$ & 12,620 \\
Oweep & 1400 & $7 / 15-9 / 10$ & 16,686 \\
Painter & 1200 & $7 / 12-9 / 6$ & 14,756 \\
Red Castle & 1300 & $7 / 6-9 / 10$ & 14,857 \\
Tungsten & 1200 & $7 / 12-9 / 6$ & 16,149 \\
Totals & 12,850 & & 160,410 \\
\hline
\end{tabular}

3) Areas without dense timber, rock, or other physical barriers.

4) Areas with naturally resilient soils (not unstable or highly erodible soils).

5) Ground cover greater than $60 \%$.

6) Areas within one mile of water or where the ability to provide water exists.

In its 2003 Forest Plan Revision, the WCNF used only Criteria 1, 2 and 6 [20]. It evaluated the slope of the land using a digital elevation model to determine where the lands of less than or equal to 45 percent slope were located. Lacking current forage production data, the WCNF used a vegetation layer as a surrogate for forage production. While forage production had been determined in the 1960s and was their most recent data, it was not used. The Final Environmental Impact Statement for the Wasatch-Cache Revised Forest Plan [20] described it thusly: "The vegetation layer was used as a surrogate for minimum forage production. In general, coniferous-forested vegetation types (spruce, fir, pine, Douglas-fir), oak, and barren areas were said to not produce the minimum 200 lbs/acre of forage. All other types were included as potential forage-producing types." The Forest Plan for the ANF was produced in 1986 prior to the publication of these recent Regional criteria. According to the ANF, the capability analysis done in the 1960s was used in the Forest Plan [24]. It does not incorporate the current Criteria. Neither Plan relied on current forage production data.

\subsection{Grazing Capability Model}

Due to the lack of a dataset for ground cover and sufficiently detailed soil surveys, our model did not exclude highly erodible soils and areas with ground cover less than $60 \%$ (criteria 4 and 5). It is of note, however, that excluding slopes greater than 45 percent by the very nature of soil erosion/slope relationships defined in the Universal Soil Loss Equation [25] would inherently exclude many areas of unstable soils or soils with high erosion hazard. Criterion 6, distance to water, was evaluated and was not a limiting factor as all areas meeting 
slope, forage production and lack of dense timber criteria 1,2 and 3 were within one mile of water. Small, isolated capable areas were removed from the final map as these are inaccessible (within dense forest) or surrounded by non-capable areas that are impractical to graze without placing the non-capable areas at risk. In sum, the model determined capable acres based on land less than one mile from water, less than or equal to 45 percent slope, producing $200 \mathrm{lb} /$ acre or more of forage (based on actual forage surveys, described below), and lacking dense timber.

The model used ESRI's ArcGIS 10.5.1 [26] and ModelBuilder [27] as the modeling environment. As the main output, we obtained a dataset in polygon format that described the landscape according to the areas capable of supporting domestic sheep grazing. Water bodies were excluded. Wetlands are not grazed by sheep, so were excluded in the model [16]. Figure 6 illustrates the steps implemented for the sheep grazing capability model by a stepwise removal of acreage $>45 \%$ slope, areas with forage production $<200 \mathrm{lb} / \mathrm{acre}$, and areas with dense forest canopy. The resulting areas which meet Forest Service capability criteria were further reduced by removing isolated areas of land meeting capability criteria due to the need to use non-capable areas for access. Then water bodies and wetlands, areas which are not grazed or are not preferred by domestic sheep, were removed. This provided a final acreage of land which the model determined is capable of being grazed without risk of excessive damage. We would qualify this by saying this depends on having stocking rates that are within the forage capacity of the areas grazed. Datasets used or generated in model development are listed in Table 2. We requested and received GIS data from the Forest Service [28] and their historic monitoring data [15] in order to perform the analysis.

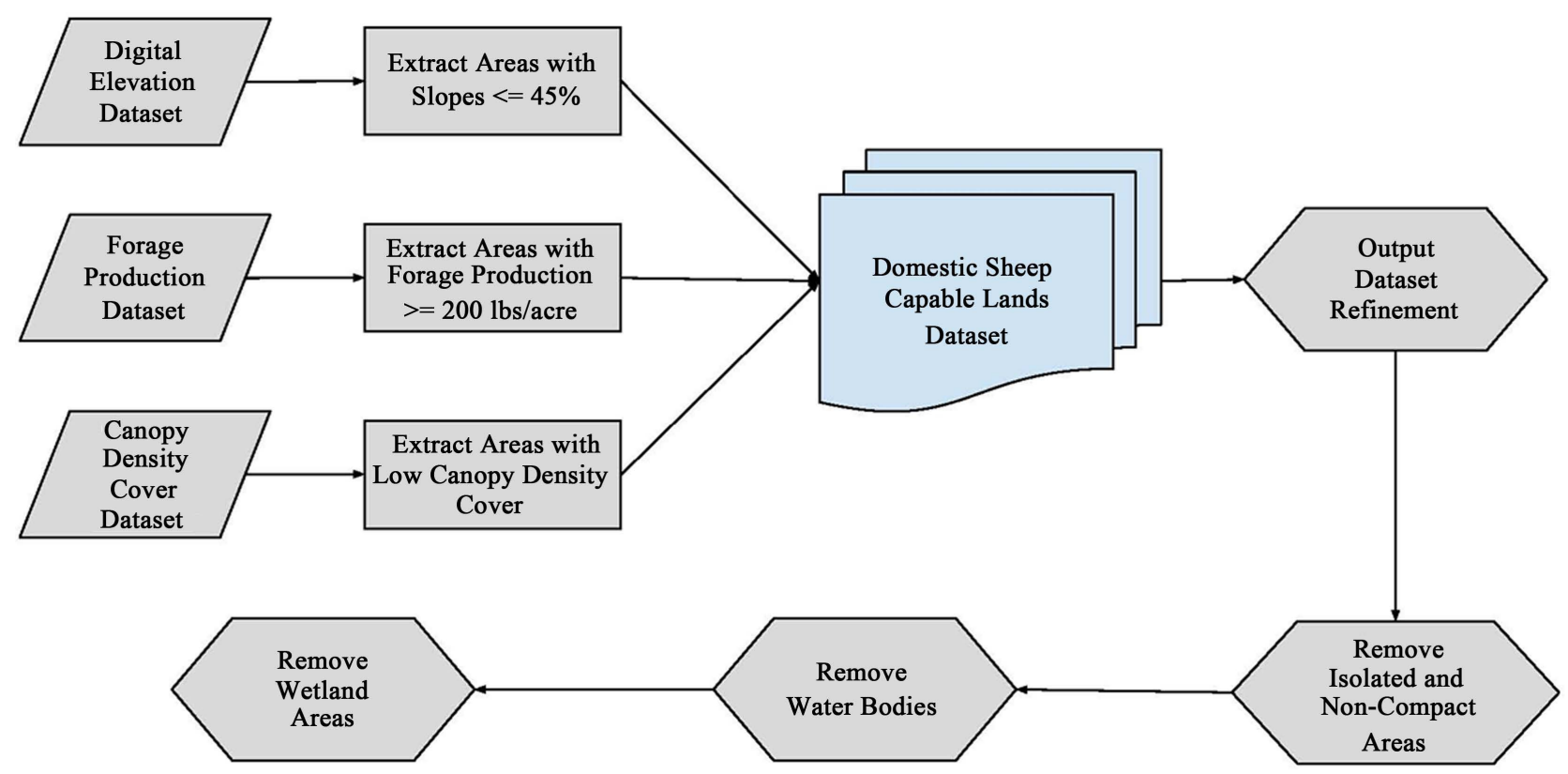

Figure 6. Flowchart of the domestic sheep grazing capability model. 
Table 2. GIS datasets.

\begin{tabular}{|c|c|c|c|c|}
\hline Dataset Name & $\begin{array}{l}\text { Format } \\
\text { Type }\end{array}$ & Version & Resolution & Source \\
\hline $\begin{array}{c}\text { NED Digital } \\
\text { Elevation Model }\end{array}$ & Raster & 2013 & 10 meters & US Geological Survey [29] \\
\hline Slope & Raster & 2018 & 10 meters & $\begin{array}{c}\text { Derived from NED } \\
\text { Digital Elevation Model }\end{array}$ \\
\hline $\begin{array}{c}\text { NAIP Digital } \\
\text { Ortho Photo Images }\end{array}$ & Raster & 2016 & 1 meter & $\begin{array}{l}\text { USDA National Agriculture } \\
\text { Imagery Program [30] }\end{array}$ \\
\hline $\begin{array}{c}\text { Canopy } \\
\text { Density Cover }\end{array}$ & Raster & 2018 & 1 meter & Wild Utah Project \\
\hline $\begin{array}{c}\text { National } \\
\text { Wetlands Inventory }\end{array}$ & Polygon & & $\begin{array}{l}\text { Version 2.0, } \\
\quad 2016\end{array}$ & $\begin{array}{c}\text { US Fish and } \\
\text { Wildlife Service [31] }\end{array}$ \\
\hline $\begin{array}{c}\text { Predicted } \\
\text { Forage Production }\end{array}$ & Raster & 2018 & 10 meters & Wild Utah Project \\
\hline $\begin{array}{c}\text { Forage } \\
\text { Production Maps }\end{array}$ & $\begin{array}{l}\text { Digitized } \\
\text { PDFs }\end{array}$ & $1960-1967$ & $1: 17,000$ & US Forest Service [32] \\
\hline $\begin{array}{c}\text { Digitized } \\
\text { Forage Production }\end{array}$ & Polygon & 1960 & $1: 17000$ & $\begin{array}{c}\text { Digitized by Wild Utah } \\
\text { Project }\end{array}$ \\
\hline $\begin{array}{l}\text { Grazing Allotments and } \\
\text { Pastures Boundaries }\end{array}$ & Polygon & 2016 & $1: 24,000$ & US Forest Service [33] \\
\hline NHD Water Bodies & Polygon & Version 1.07 & $1: 24,000$ & US Geological Survey [34] \\
\hline $\begin{array}{c}\text { Grazing Capability } \\
\text { (Forest Plan Revision) }\end{array}$ & Polygon & 2001 & $1: 24,000$ & US Forest Service [35] [36] \\
\hline $\begin{array}{l}\text { Forage Production } \\
\text { Survey Sites }\end{array}$ & Point & 2016 & N/A & Wild Utah Project \\
\hline Soils & Polygon & 2011, 2016 & $1: 24,000$ & US Forest Service [37] [38] \\
\hline
\end{tabular}

\subsection{Development of Model Parameter Inputs}

Slope: Criterion 1 as interpreted in the WCNF Revised Forest Plan [20] defines areas with slope $\leq 45 \%$ as capable for domestic sheep grazing. Determination of such areas was made using the Slope Analysis tool within the ESRI ArcGIS software [26]. As the chief input dataset, the NED Digital Elevation Model was used to derive the slope raster file [29] (Table 2). In a follow-up process, the output slope raster was filtered in order to generate a raster dataset containing areas with slopes $\leq 45 \%$.

Forage Production: To refine the vegetation production estimate used by the Forest Service, we obtained field data for actual forage production. In order to get a representative sample of available forage in the project area, our team relied on areas that were not grazed by livestock prior to field sampling which occurred in August, 2016. Using soil map files [37] [38] and soil descriptions [39] obtained from the Forest Service, we determined that seven soil types were most common in the UWCNF portion of the project area which was not grazed prior to sampling. These occurred in the ungrazed areas and could be sampled to de- 
termine forage production. Of these soil map units, the Rubble and Rock Outcrop type covers 17,219 acres or almost $22 \%$ of the UWCNF study area, and is largely barren high county, so would not be expected to contain enough forage to factor into a grazing capacity analysis. Therefore, this soil type was not sampled and was assigned a value of zero for forage. The six remaining soil types were then visited by field teams in August, 2016 to collect forage production samples. Sites were inspected for signs of current sheep use such as droppings, tracks, bedding areas, and visible grazing use, in order to exclude these from the forage capacity samples if they were determined to have been grazed that season.

Sample site locations for collecting forage data were determined from locations of Forest Service monitoring sites and complemented with random locations generated with GIS to ensure coverage of all soil types. The number of locations was distributed equally among the soil types. Thirty-six locations were sampled across the 6 common soil types. At each pre-determined location within each soil type, plot clippings were collected along a transect heading due north [40]. To collect plot clippings, $24 \times 24$-inch sample frames were placed at $25^{\prime}$, 50', 75' and 100' along each 100' transect. All herbaceous species in each sample plot were clipped to one inch above the ground, placed in Ziploc bags and brought back to camp, where they were kept open to air out until transported to the lab where they were air dried and weighed on an electronic balance. The amount of air-dry forage per acre was then calculated.

The forage production samples were then correlated with the aerial ortho-photos of the study area. Figure 7 illustrates the process of correlation and

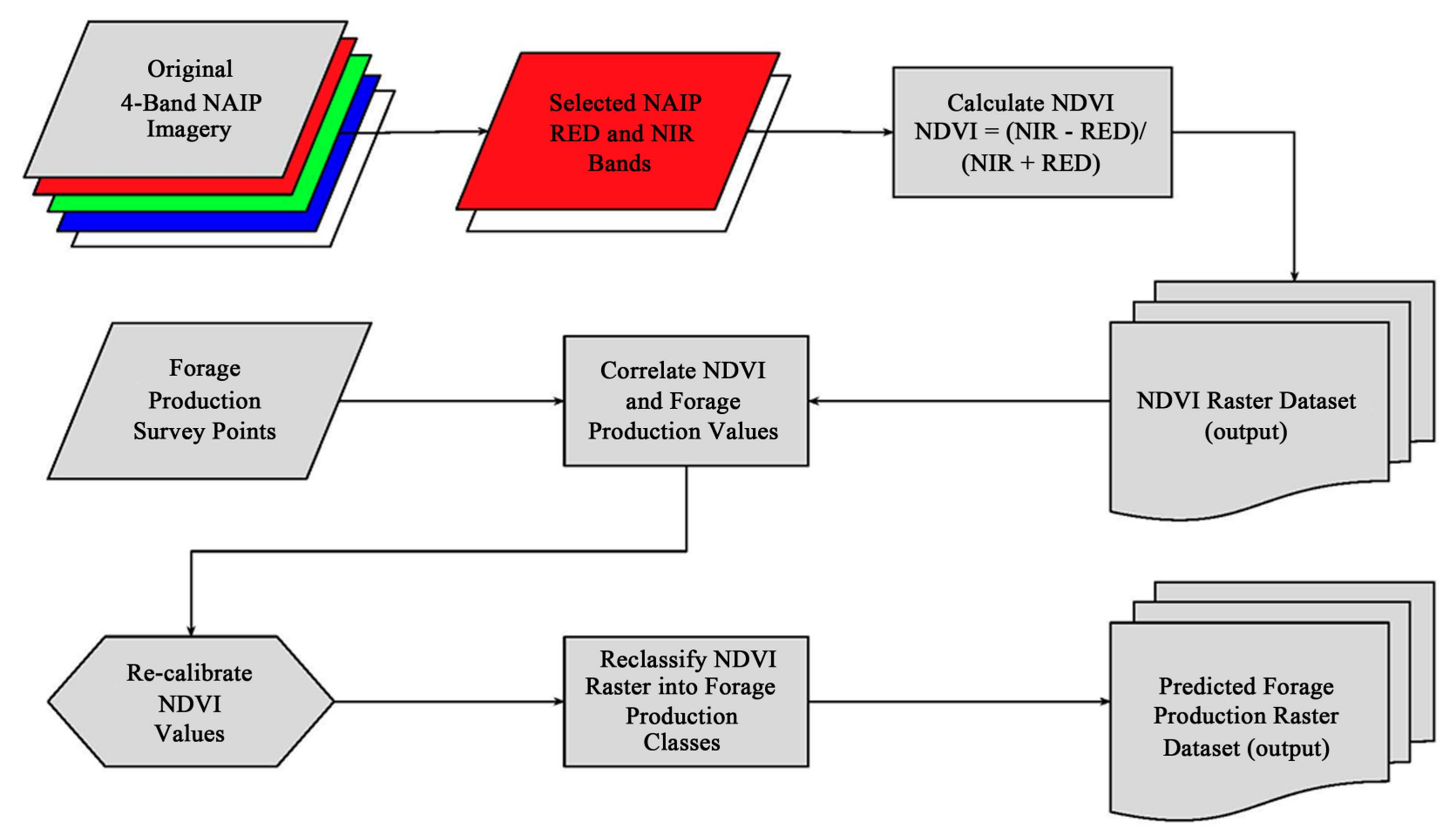

Figure 7. Image analysis process for the estimation of NDVI values, correlation of NDVI with forage production survey points, and image classification to derive a predicted forage production raster dataset. 
NAIP image classification that was applied to derive a predicted forage production raster layer, using the Image Analysis tools within ESRI ArcGIS [20]. In the first step, we utilized NAIP imagery from August, 2016 to estimate Normalized Difference Vegetation Index (NDVI) values across the study area [30] (Figure 8). NDVI is estimated based on a ratio between the red and near-infrared (NIR) optical bands embedded in the NAIP imagery. The equation for NDVI is presented as NDVI $=(\mathrm{NIR}-\mathrm{RED}) /(\mathrm{NIR}+\mathrm{RED})$. This mathematical operation was completed by using the Raster Calculator in ArcGIS which generated a raster file. In the next step, the forage production survey points were used to correlate those values to the NDVI values from the previous step (Figure 9). These two datasets were correlated to each other by using the pixel values in the NDVI raster dataset and the forage production values determined at each survey location. By using the data correlation, we were able to re-calibrate the NDVI values to forage production values and confidently conduct a raster classification into different forage production classes based on the differential raster values of those vegetation classes (Figure 10).

Dense Timber: Areas of dense timber are considered not capable in the Forest Service Criteria because livestock generally avoid grazing in areas of thick conifer cover, either due to lack of forage or access limitations. In the model, areas with high and medium canopy density were excluded from capable areas since those canopy density categories are associated with areas with dense timber, a large number of fallen trees, and areas with restricted access to livestock. In order to achieve a reliable dataset that would describe areas of dense timber throughout the study area, we revisited the NDVI raster dataset from the previous

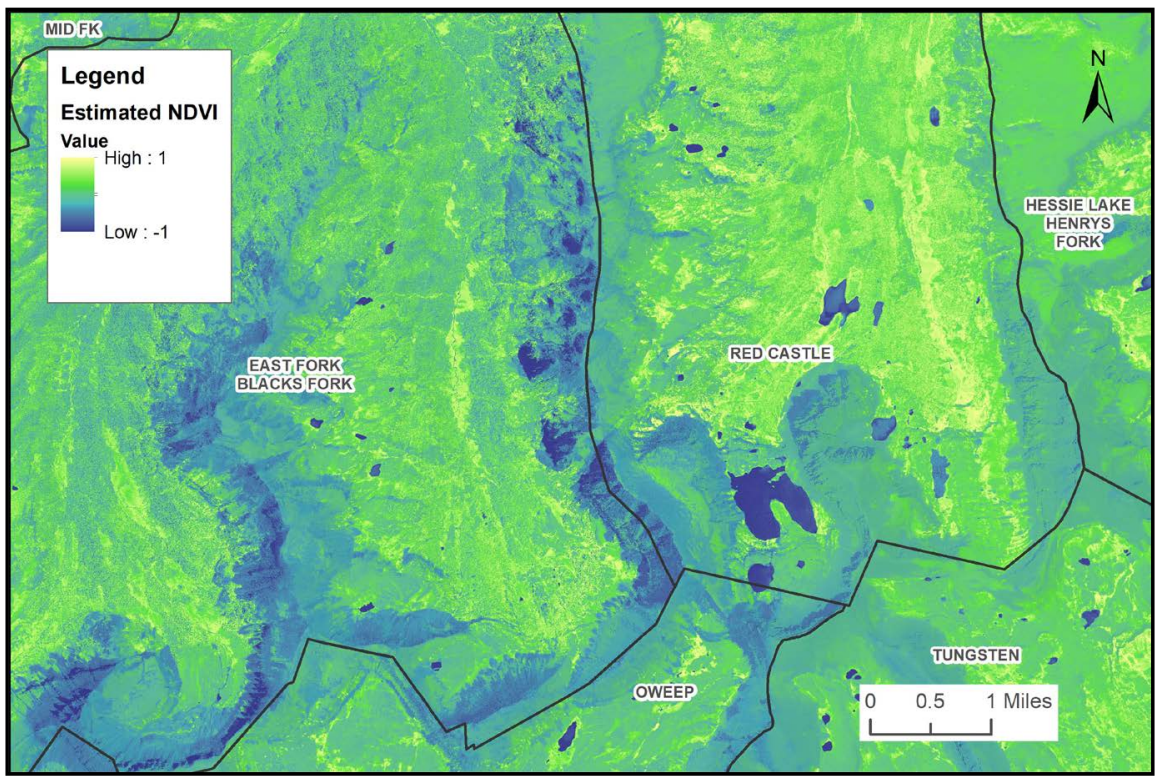

Figure 8. NDVI raster obtained from image analysis operation by estimation of a ratio between the green and near-infrared bands in NAIP ortho photo images [30]. (Areas shown in blue represent water bodies and areas shown in various shades of green represent vegetation in various NDVI values). 


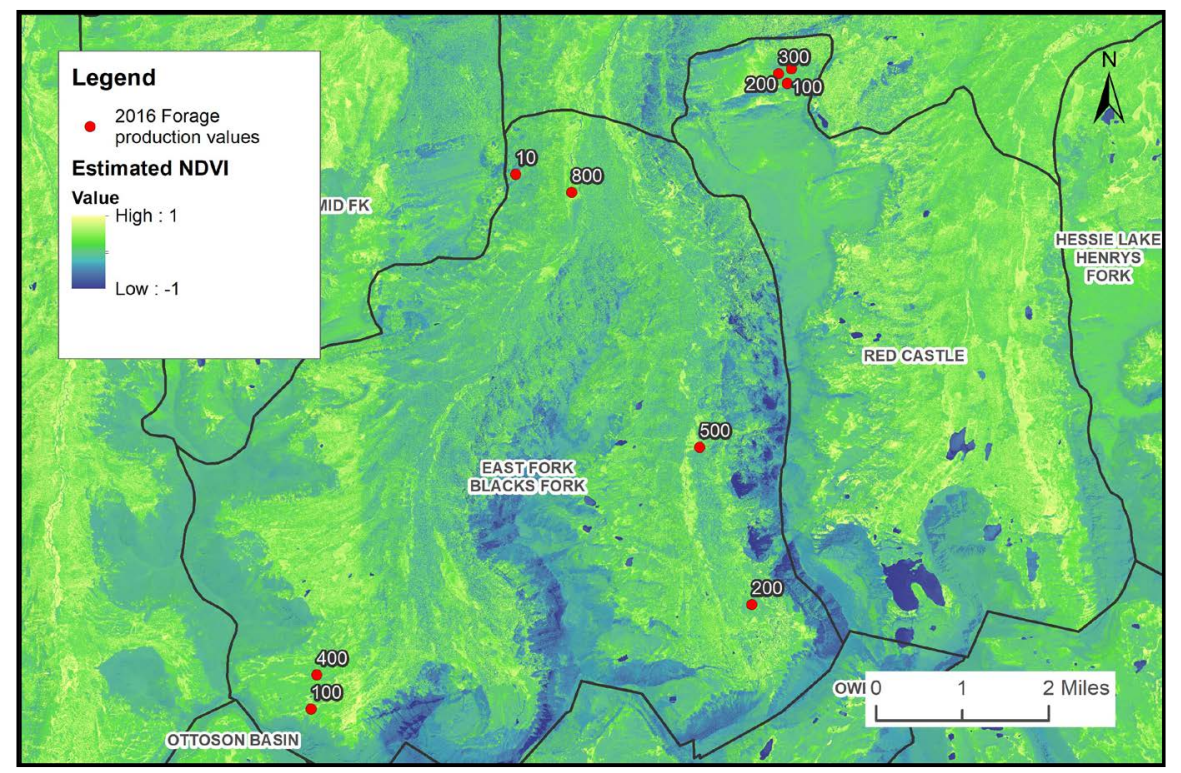

Figure 9. NDVI raster and forage production values estimated from the survey conducted in 2016.

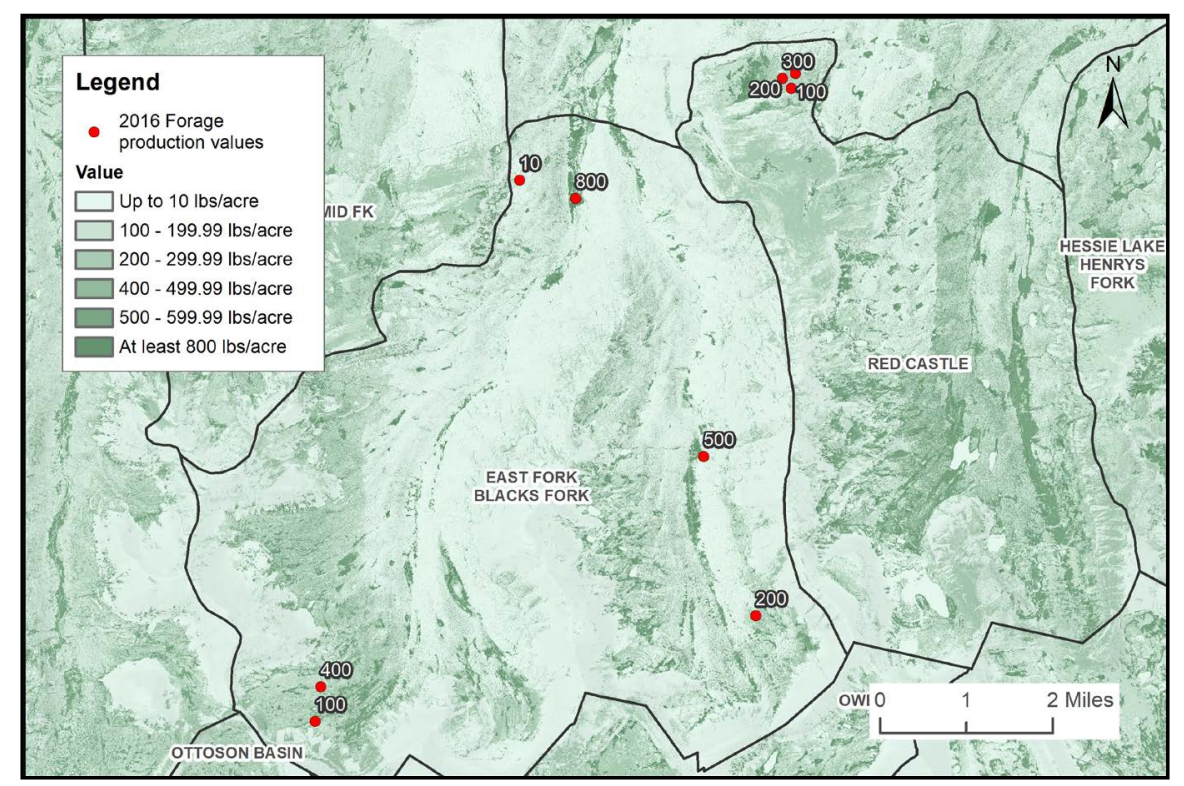

Figure 10. Predicted forage production raster from image classification of forage production data.

process and adjusted the raster classification process by targeting the different levels of forest canopy density. The resulting dataset describes the study area in terms of canopy density levels (i.e. high to low). Figure 11 illustrates the data transformation process to obtain the canopy density cover dataset. Figure 12 shows the resulting forest canopy density raster dataset.

Comparisons Using Model Outputs: Once these model outputs were derived, we made two comparisons to the Forest Service determination of capable lands. In Case 1, we calculated the acreage of lands meeting current Criteria of $\leq 45 \%$ slope, 2016 forage production $\geq 200 \mathrm{lb} / \mathrm{acre}$, and excluded areas of dense timber, 


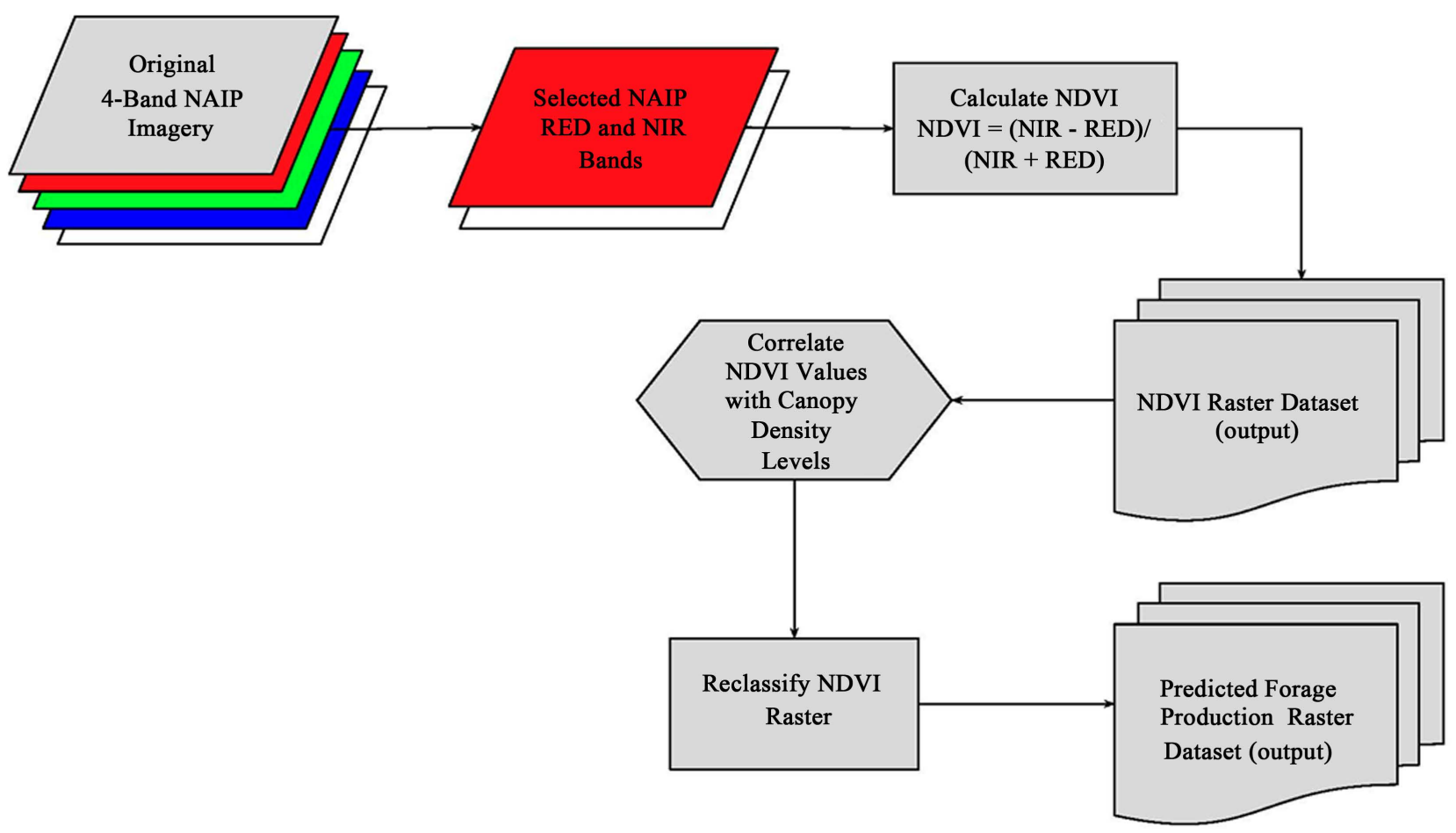

Figure 11. The data transformation process to obtain the canopy density cover dataset.

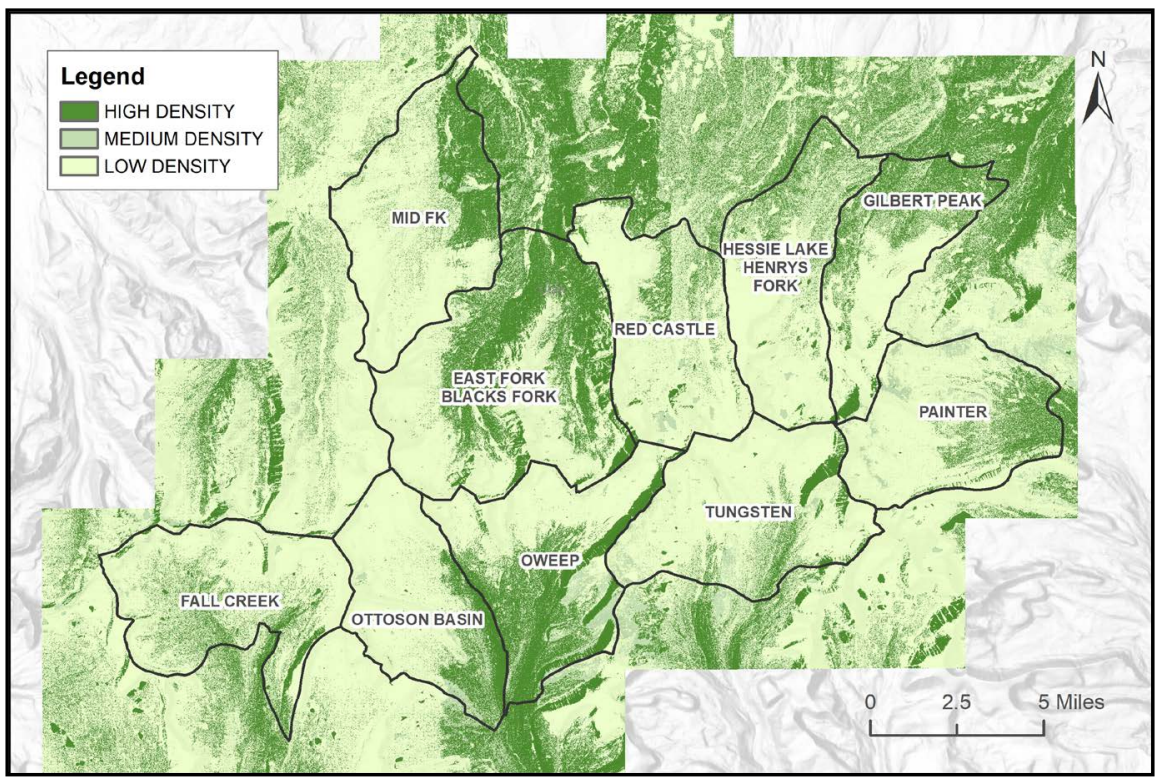

Figure 12. Canopy density raster dataset using NDVI values from NAIP imagery and the resulting classification into density categories.

water bodies and wetlands. In Case 2, since the most recent Forest Service forage production data was that collected in the 1960s, we digitized the 1960's forage production data which was then used to determine acres with forage production $\geq 200$ lbs/acre [32] (Table 2). This, along with slope $\leq 45 \%$ and excluding areas of dense timber, water bodies and wetlands were used to determine capable acres. 


\subsection{Stocking Rate Determination}

Forage Consumption: A forage consumption rate for sheep was provided in the USFS Region 4 Range Analysis Handbook showing forage consumption for a $125 \mathrm{lb}$ ewe to be $4.1 \mathrm{lb} /$ day air dry weight while an 80 - $90 \mathrm{lb}$ lamb would consume $2.9 \mathrm{lb} /$ day [22]. Since permits allow two lambs per ewe, we used $9.9 \mathrm{lb} /$ day (301 lb/month) as a forage consumption rate for each ewe/lamb pair applied to the permitted numbers for each allotment. According to government statistics, in 2017, the average live weight of sheep and lambs for slaughter was 132 pounds [41]. This indicates our estimated forage consumption rate for a ewe and two lambs could be an underestimate if full permitted numbers of ewes and lambs are being grazed.

Utilization: Recommended utilization rates are $20 \%$ for alpine ranges grazed during the growing season or in poor condition, while for ranges in good condition and grazed during the dormant season $30 \%$ is recommended [42]. Lewis (1970) recommended 30\% utilization for all areas except wetlands [16]. He recommended $40 \%$ in wetlands, while acknowledging these are not preferred by sheep, are not suitable for grazing and that the drier uplands nearby will be preferred. For this analysis we used a 30\% utilization rate even though past work has shown these alpine and subalpine upland areas to be in poor condition with depleted ground cover, gully erosion, stream bank scouring and heavy grazing in non-capable areas such as uplands and steep slopes, indicating that they are most often in poor condition [16] [18] [19].

\section{Results and Discussion}

\subsection{Current Forage Production and Comparison to 1960's Data}

The 1960's forage production data excluded non-forage species in grazing capacity determinations [15] [16] [22]. Table 3 summarizes key statistics from the 1960's determinations and our 2016 forage production data set.

The median sample weight was less in 2016 than in the 1960s while the mean was greater in 2016. This is logical since the 2016 data included all herbaceous species whether forage or non-forage, while the 1960s' data did not include non-forage species. The 2016 maximum values were samples from wetlands. The highest non-wetland sample was near the 1960's maximum.

\subsection{Comparison of Capable Acres}

Table 4 summarizes the capable acres determined for the ten allotments applying the current Criteria. These are contrasted with those determined by the ANF and WCNF in their Forest Plans. The Forest Service determination of capable

Table 3. Key statistics for forage production (lb/acre).

\begin{tabular}{cccc}
\hline Time Period & Median & Mean & Maximum \\
\hline 1960 s & 206 & 240 & 615 \\
2016 & 166 & 294 & 1431 \\
\hline
\end{tabular}


lands was represented in the GIS data they provided [35] [36]. Their determination was that $35.7 \%$ of the land area was capable (Table 4 and Figure 13). They did not exclude areas of dense timber or wetlands and did not collect forage production data, while relying on assumed production from their vegetation layer. Case 1 resulted in only $6 \%$ of the total allotment area being capable (Figure 14). Case 2 resulted in only $1.8 \%$ of the total allotment area being capable (Figure 15). The Forest Service determination of capable lands overestimates the actual amount by nearly 6 times based on applying their current Criteria and our 2016 forage production data (Case 1) and nearly 20 times when the 1960's

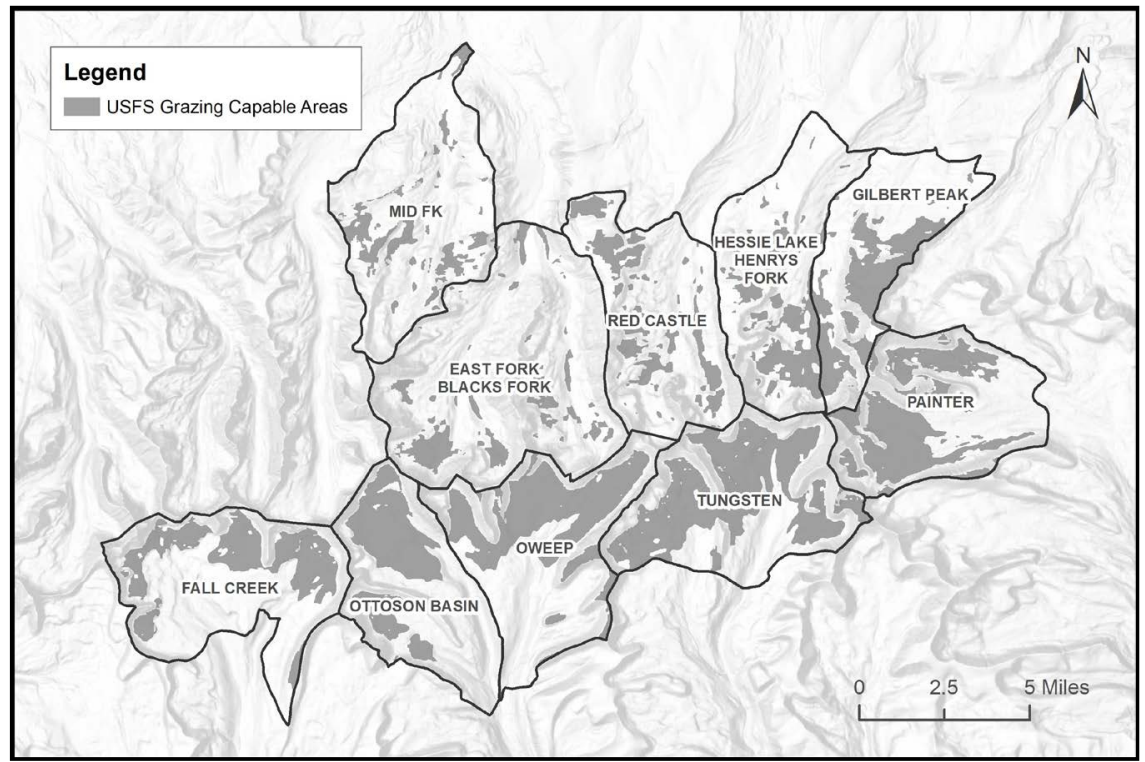

Figure 13. Ashley and Wasatch-Cache National Forest determination of capable acres = 57,399 acres, or 35.7 percent of total acres.

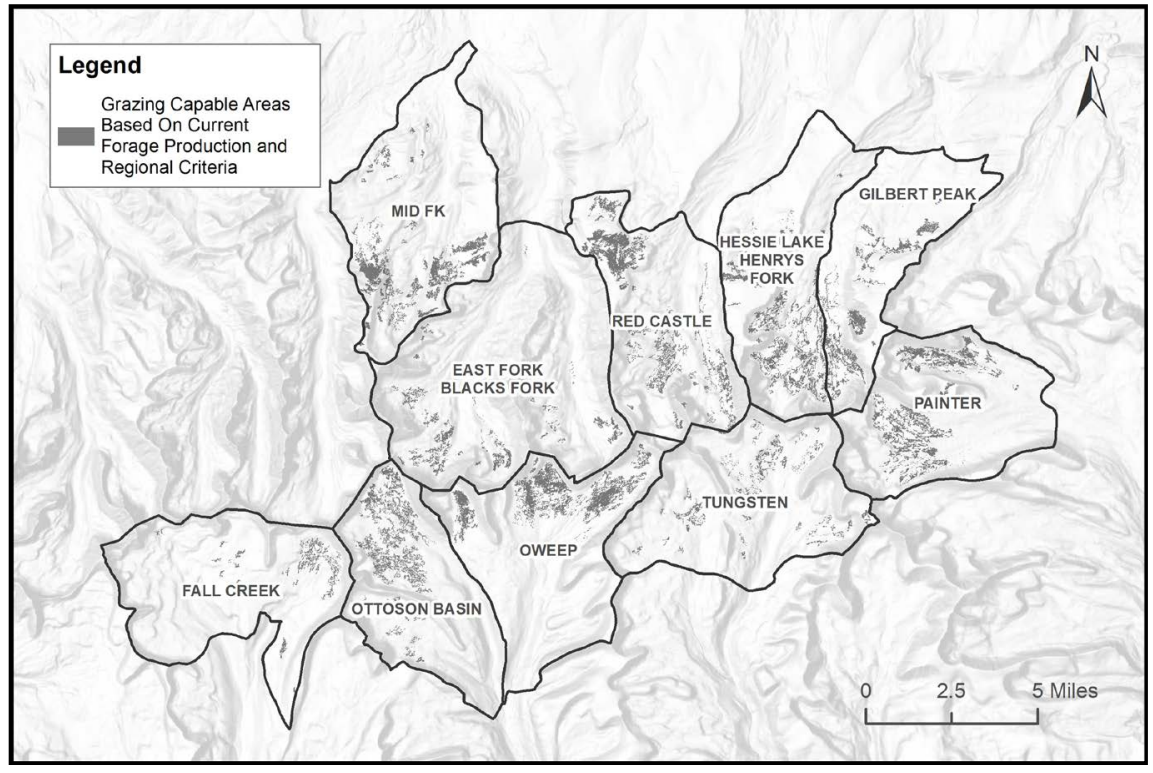

Figure 14. Capable acres determined from regional capability criteria and current forage production $=9685$ acres, or 6.0 percent of total acres. 


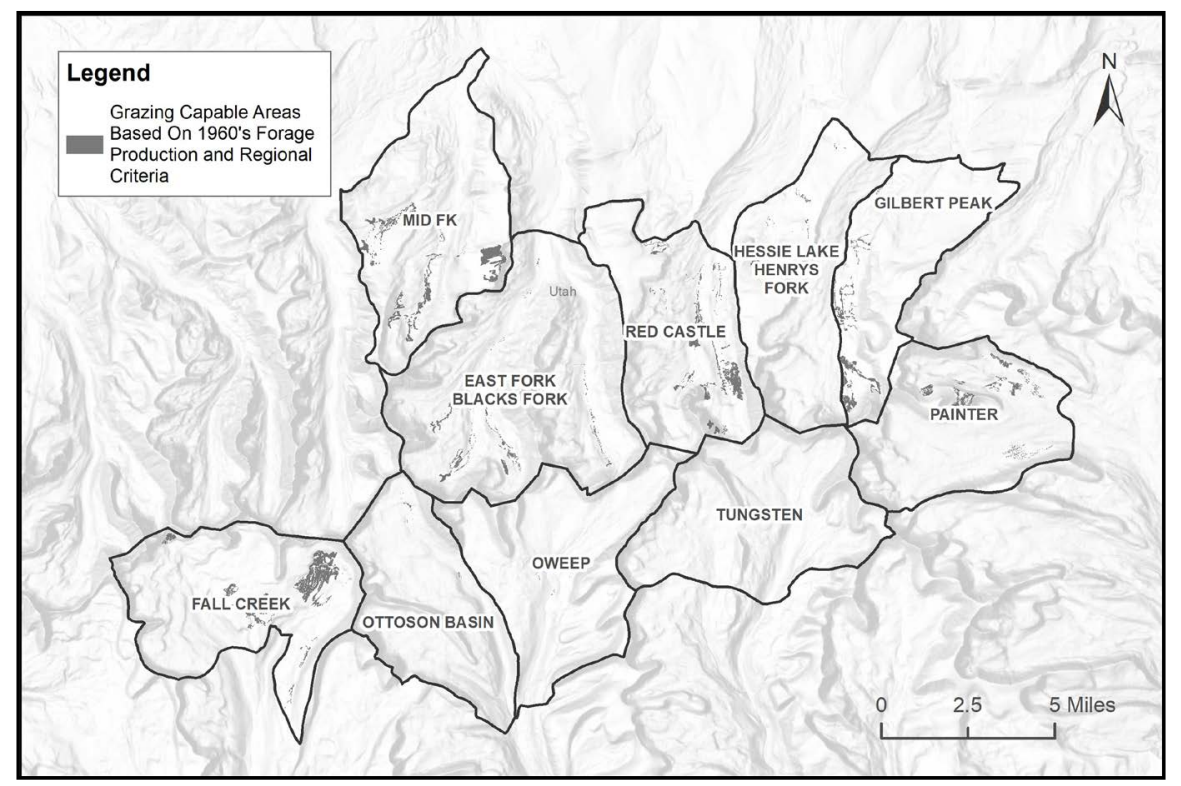

Figure 15. Capable acres determined from regional capability criteria and 1960's forage production $=2.887$ acres or 1.8 percent of total acres.

Table 4. Summary of capable acres.

\begin{tabular}{cccc}
\hline $\begin{array}{c}\text { Total } \\
\text { Allotment } \\
\text { Acres }\end{array}$ & $\begin{array}{c}\text { Forest Service } \\
\text { Capable Acres }\end{array}$ & $\begin{array}{c}\text { Total Capable } \\
\text { Acres Current } \\
\text { Forage: Case 1 }\end{array}$ & $\begin{array}{c}\text { Total Capable } \\
\text { Acres 1960s } \\
\text { Forage: Case 2 }\end{array}$ \\
\hline 160,410 & 57,399 & 9685 & 2887 \\
Percent of Total & $35.7 \%$ & $6.0 \%$ & $1.8 \%$ \\
\hline
\end{tabular}

forage production data were applied (Case 2). If sufficiently detailed soil survey information and ground cover data were available, more areas would likely be found not capable as indicated by past surveys [16] [18] [19]. However, even in the absence of these data, our model demonstrates that the allotments lack land capable for grazing domestic sheep.

\subsection{Evaluation of Forage Demand, Available Forage and Stocking Rates}

The total forage demand for the currently permitted 12,850 ewe/lamb pairs grazing these ten allotments based on their time in the allotments and a forage demand of 301 pounds per month per pair is 8,062,641 pounds (Table 5). In Case 1, using the 2016 mean forage production of $294 \mathrm{lb} /$ acre and 9685 capable acres gives total forage production of $2,847,390$ pounds. Applying a $30 \%$ utilization rate to this amount gives 854,217 pounds available. This is $10.6 \%$ of the current demand. In Case 2, using the 2016 mean forage production values on the 2887 capable acres is 848,778 pounds. Applying a $30 \%$ utilization rate to this amount gives 254,633 pounds available. This is $3.2 \%$ of the demand. The implication of this to current stocking rates is clear. In Case 1, a $90 \%$ reduction would be needed to balance domestic sheep use by the current permitted numbers to 
Table 5. Forage demand compared to available forage.

\begin{tabular}{cc}
$\begin{array}{c}\text { Total Forage Demand for 12,850 ewe/Lamb Pairs } \\
\text { for the Current Grazing Period }\end{array}$ & $8,062,641$ lbs. \\
\hline Case 1: Available Forage on 9685 Capable Acres & 854,217 lbs. or 10.6\% of Total Demand \\
Case 2: Available Forage on 2887 Capable Acres & 254,633 lbs. or 3.2\% of Total Demand
\end{tabular}

the available forage. In Case 2, a 97\% reduction would be needed to balance domestic sheep use by the current permitted numbers to the available forage.

Where does the additional forage to support these 12,850 ewe/lamb pairs of permitted sheep come from? The domestic sheep are grazed and trailed throughout the non-capable areas on steep slopes and highly erodible soils and in the sensitive alpine meadows, where sheep consume whatever small amounts of edible plants they can find. This management has caused and continues to cause accelerated erosion, high flood forces during runoff events, changes in plant communities, and erosion of streambanks [16] [18] [19].

\subsection{Impact on Wilderness Values}

Cole and Landres (1996) delineated the threats to wilderness ecosystems to include: 1) recreation; 2) livestock grazing; 3) fire management; 4) invasive species; 5) diversion and impoundment of water; 6) atmospheric pollutants; and 7) management of adjacent lands [43]. Here we are considering only the livestock grazing effects, which they delineate as trampling, grazing, defecation, death of plants, compaction and destabilization of soils, redistribution of nutrients, changes in geomorphology, gully formation, and lowering of water tables, reduced water quality and impacts on wildlife populations. They considered the most significant effect at the species level is the indirect effects on wildlife. They point out that many of these wilderness areas are located at high elevations or in the desert, are naturally stressed and not resilient.

We have described the ecological degradation of plant and soil communities occurring in the High Uintas Wilderness due to grazing in non-capable areas. In addition, the current large-scale removal of vegetation by domestic sheep grazing in the High Uintas Wilderness reduces food and cover for native wildlife that depend on herbaceous plants. Snowshoe hares (Lepus americanus) are a principle food source for Canada lynx (Lynx canadensis), a Threatened species. Grazing by domestic sheep may be playing a role in the current absence of lynx from the High Uinta Wilderness [44]. Bighorn sheep populations today are a small fraction of historical numbers, with a loss of over 98 percent of historic numbers [45]. Domestic sheep compete with native bighorn sheep for food, space and water. They are also asymptomatic carriers of diseases such as pneumonia that result in sick and dead bighorn sheep if the two come into contact with one another [46].

The ANF and UWCNF have monitored many locations in these ten grazing allotments and, in recent years, have not identified impacts of domestic sheep 
grazing. For example, the Forest Service notes that "over 99\% of the studies show ground cover is in satisfactory condition" and plant communities are dominated by plants of high value for watershed protection [2]. We reviewed the data files, photographs and data sheets provided by the Forest Service [15] and analyzed the Forest Service monitoring locations [28] to determine why they failed to find the problems documented by earlier Forest Service range and soil scientists and one of our own authors which documented severe erosion, active gully progression or headcutting, streambank scouring, and lack of ground cover in the drier uplands and on steeper slopes [16] [18] [19] (Figure 16 and Figure 17). When long term ungrazed areas were compared to areas that continue to be grazed by domestic sheep, ground cover was high in the ungrazed areas, gully erosion and headcuts were healing, and streambanks were healthy and not eroding [18]. Lewis (1970) showed definitive improvements in plant community composition with improved vigor in an area where sheep had been excluded for 11 years leading to a change in condition assessment from fair to good [16].

Using GIS, we compared the Forest Service monitoring locations to percent slope and found that $59 \%$ of monitoring locations were in areas $<10 \%$ slope, and $83 \%$ in areas $<20 \%$ slope. This indicated that Forest Service monitoring was focused in areas that are less likely to be unstable and are less sensitive to sheep grazing impacts. Few sites were monitored in areas $>40 \%$ slope which would be on the slopes more subject to erosion and instability. Eighty three percent of locations were in riparian areas, alpine wet and dry meadows and willow complexes which are the less sensitive areas and many that are least preferred by sheep and which also correspond to more level terrain. Forest Service ground cover data is rarely collected. If casual observations noted in their files as well as on data sheets are all counted, only $10.8 \%$ of the monitoring sites since 2000 noted a ground cover estimate. The satisfactory conditions the Forest Service noted in their Draft Environmental Impact Statement appear to logically follow, given these measures were taken in the areas less sensitive to domestic sheep impacts [2].

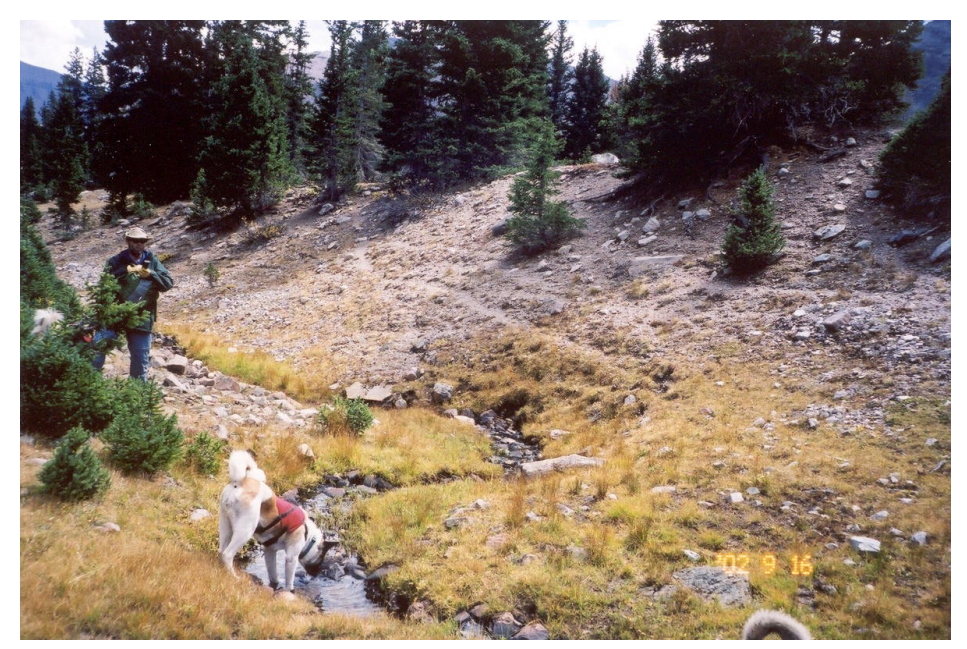

Figure 16. Upland adjacent to riparian area showing bare soils and trailing damage [18]. 


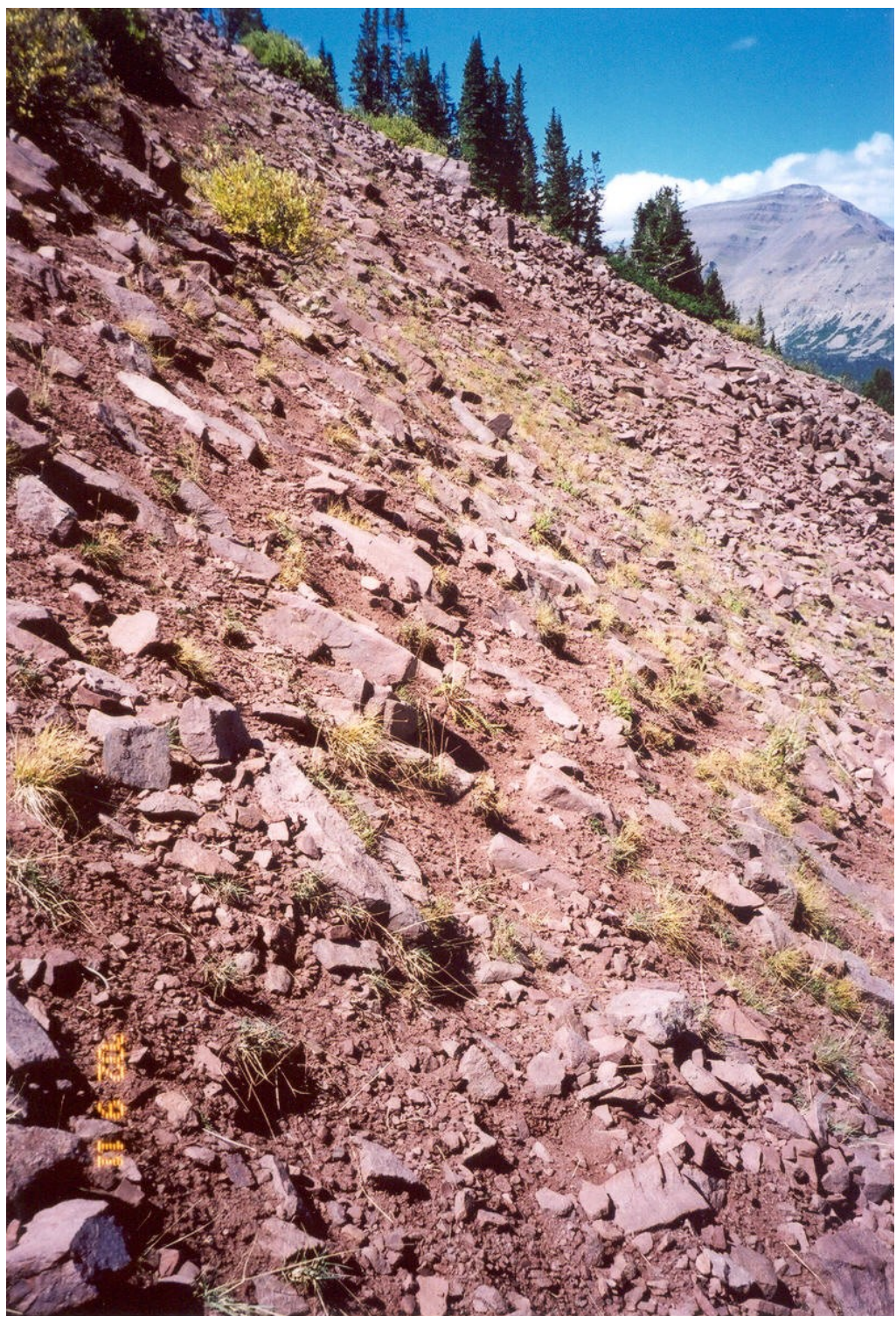

Figure 17. Result of sheep grazing on steep slopes leaving loose, erodible soil and sparse plant cover [18].

Cole and Landres (1996) [43] note: "We can, however, attempt to identify those places where grazing is most inappropriate and develop grazing management objectives and guidelines that are more compatible with the goals of wilderness than the goal of maximizing sustainable animal production (the most common goal outside wilderness)". Wilderness is "land retaining its primeval character and influence, without permanent improvements or human habitation, which is protected and managed so as to preserve its natural conditions...." In addition, wilderness should be "affected primarily by the forces of nature, with the imprint of man's work substantially unnoticeable. By these definitions alone, domestic sheep grazing is incompatible with the Wilderness Act. The degradation documented in the Uinta Wilderness over the decades is clearly not compatible with the Wilderness Act's intent. 


\section{Conclusions}

The GIS analysis we have conducted for the High Uintas Wilderness Domestic Sheep grazing reauthorization indicates that only a small fraction of these allotments are capable of supporting domestic sheep grazing. The capable acres identified in our forage capacity model for this mountain range are scattered, small areas disconnected from each other to a large extent and require sheep to be trailed between them. Historically, nearly every acre sheep can access has been grazed across the Uinta mountains, regardless of slope, ground cover, elevation, soil erosion hazard and vegetation condition. Previous monitoring has identified that large-scale erosion is occurring in the High Uintas Wilderness due to this practice of trailing and grazing domestic sheep in non-capable areas.

This analytical process using GIS provides a framework for evaluation of other grazed lands and an evaluation of the costs and benefits of livestock grazing versus other values such as wildlife, native plant communities and water supplies. It shows that current and proposed Forest Service management is based on lack of compliance with its own Regional Capability Criteria, inadequate monitoring and insufficient analysis. Limitations of the study include the lack of a suitably detailed soil survey to determine erosion susceptibility, a lack of ground cover data, a lack of Forest Service data for the level of grazing use, or utilization, and the lack of a Forest Service quantitative measurement of vegetation production in each plant community and soil type. In spite of these limitations, the use of slope, forest cover and forage production as derived in our study reduced field work necessary to do this evaluation and showed that these were the dominant factors needing to be addressed.

Forest Service management can address the problems in the High Uintas Wilderness by applying the analytical process we have provided and adjusting stocking rates and grazing periods based on the capable acres, current forage production and forage consumption rates, while applying a sustainable utilization rate. Sheep should be managed to remain within the capable areas and away from steep slopes. Monitoring should include trend in ground cover and utilization. It should be standardized, quantitative and performed annually. It should include capable and non-capable areas with a focus on those areas most preferred by domestic sheep such as the dry meadows and uplands in the valleys, uplands at the margins of wet areas and slopes at the valley margins. Sufficiently detailed soil surveys should be carried out for future evaluations. Only then will the Forest Service approach conditions where domestic sheep grazing in this wilderness may be sustainable and recovery of past degradation can begin.

\section{Acknowledgements}

We are grateful to Cindy Oprandy and Darlene Voerner for their input, data, photographs and descriptions provided from their work in the Uintas as soil scientists for the Ashley National Forest. We also wish to acknowledge Mont Lewis, Range Conservationist for the US Forest Service who provided the first 
integrated look at domestic sheep grazing impacts in the Uinta Wilderness.

Allison Jones and Emanuel Vasquez were supported in this work through general funding by the Wild Utah Project, a 501c3 organization for which they worked at the time of the analysis presented herein.

Dr. Carter has spent decades surveying and exploring the High Uintas Wilderness both at his own expense and while in the 2001-2010 time period he was an employee of Western Watersheds Project (WWP), also a 501c3 organization. Since retiring from WWP 2010, he has donated his time and expenses to this work. This research did not receive any specific grant from funding agencies in the public, commercial, or not-for-profit sectors.

\section{Conflicts of Interest}

The authors declare no conflicts of interest regarding the publication of this paper.

\section{References}

[1] U.S. Department of Agriculture (USDA) (2014) Scoping Notice-High Uintas Wilderness Domestic Sheep Analysis. Uinta-Wasatch-Cache National Forest, Salt Lake City, UT.

[2] U.S. Department of Agriculture (USDA) (2019) Draft Environmental Impact Statement High Uintas Wilderness Domestic Sheep Analysis. Ashley and UintaWasatch-Cache National Forests. Salt Lake City, UT.

[3] Gabathuler, E., Liniger, H., Hauert, C. and Giger, M. (2009) Benefits of Sustainable Land Management. World Overview of Conservation Approaches and Technologies, Center for Development and Environment, University of Bern, Bern, Switzerland.

[4] Fleischner, T. (1994) Ecological Costs of Livestock Grazing in Western North America. Conservation Biology, 8, 629-644. https://doi.org/10.1046/j.1523-1739.1994.08030629.x

[5] Wilderness Watch (WW) (2019) The Cattle Compromise: Livestock's Damaging Effect on Wilderness and the Way Toward a Livestock-Free Wilderness System. Wilderness Watch, Missoula, MT. https://wildernesswatch.org/images/wild-issues/2019/01-2019-WW-Policy-Paper-G razing.pdf

[6] U.S. General Accounting Office (GAO) (1988) Rangeland Management: More Emphasis Needed on Declining and Overstocked Grazing Allotments. Washington DC.

[7] Utah State University Extension (USU) (2019) Utah Major Watersheds. https://extension.usu.edu/waterquality/learnaboutsurfacewater/watersheds/utahmaj orwatersheds

[8] Bates, W. and Jones, A. (2007) Least-cost Corridor Analysis for Evaluation of Lynx Habitat Connectivity in the Middle Rockies. Wild Utah Project, Salt Lake City, UT. https://app.box.com/s/0g8b1ryqg1iz6r1fd61rdkc8fso97oh5

[9] Lewis, L. and Wenger, C.R. (1998) Idaho's Canada Lynx: Pieces of the Puzzle. Idaho Bureau of Land Management Technical Bulletin No. 98-15.

https://doi.org/10.5962/bhl.title.63223

[10] Jones, A., Catlin, J., Lind, T., Frelich, J., Robinson, K., Flaherty, L., Molvar, E., Kess- 
ler, J. and Daly, K. (2004) The Heart of the West Conservation Plan. Wild Utah Project, Salt Lake City, UT.

https://wildlandsnetwork.org/resources/heart-west-conservation-plan/

[11] Noss, R., Wuerthner, G., Vance-Borland, K. and Carroll, C. (2001) A Biological Conservation Assessment for the Utah-Wyoming Rocky Mountains Ecoregion: Report to The Nature Conservancy. Conservation Science, Inc., Corvallis, OR. https://www.conservationgateway.org/ConservationPlanning/SettingPriorities/Ecor egionalReports/Documents/uwrm plan ver2001.pdf

[12] U.S. Department of Agriculture (USDA) (2003) Revised Forest Plan Wasatch-Cache National Forest. Salt Lake City, UT.

[13] Jones, A. (2000) Effects of Cattle Grazing on North American Arid Ecosystems: A Quantitative Review. Western North American Naturalist, 60, 155-164.

[14] Belsky, A.J., Matzke, A. and Uselman, S. (1999) Survey of Livestock Influences on Stream and Riparian Ecosystems in the Western United States. Journal of Soil and Water Conservation, 54, 419-431.

[15] U.S. Department of Agriculture (USDA) (2019b) Historical Range Analysis and Monitoring Data for the Ashley and Uinta-Wasatch-Cache National Forests. Region 4 Forest Service. Ogden, UT.

[16] Lewis, M. (1970) Alpine Rangelands of the Uinta Mountains, Ashley and Wasatch National Forests. Region 4 Forest Service. Ogden, UT. https://app.box.com/s/mdf4yl6ss5glbip50kd6hh4fayczi4qr

[17] Munroe, J.S., Klem, C.M. and Bigl, M.F. (2013) A Lacustrine Sedimentary Record of Holocene Periglacial Activity from the Uinta Mountains, Utah, U.S.A. Quaternary Research, 79, 101-109. https://doi.org/10.1016/j.yqres.2012.12.006

[18] Carter, J. (2007) Watershed Conditions-Uinta Wilderness, Utah, West Fork Blacks' Fork, East Fork Blacks' Fork, Lake Fork, Middle Fork Beaver Creek, Burnt Fork. Western Watersheds Project, Hailey, ID. https://app.box.com/s/944957604b8618539585

[19] Oprandy, C. and Voerner, D. (2019) Photographs and Notes Provided to the Authors.

[20] U.S. Department of Agriculture (USDA) (2003b) Final Environmental Impact Statement Wasatch-Cache National Forest Revised Forest Plan: Appendix B9. Salt Lake City, UT.

[21] U.S. Department of Agriculture (USDA) (1986) Ashley National Forest Land and Resource Management Plan. Ashley National Forest, Vernal, UT.

[22] U.S. Department of Agriculture (USDA) (1964) R4 Range Analysis Handbook. Region 4 U.S. Forest Service. Ogden, UT. https://app.box.com/shared/sfq4pr9p2k

[23] U.S. Department of Agriculture (USDA) (1998) Rangeland Capability and Suitability Determinations for Forest Plan Revisions R-4 Revised 2/20/98. Region 4 Forest Service, Ogden, UT.

[24] U.S. Department of Agriculture (USDA) (2016) Interoffice Email Communication from Sandra Remund-Kaminski to Paul Cowley Stating They Used the 1960's Determination of Capable Lands for the Ashley National Forest Allotments.

[25] U.S. Department of Agriculture (USDA) (1978) Predicting Rainfall Erosion Losses: A Guide to Conservation Planning. Agriculture Handbook No. 537. https://www.ars.usda.gov/ARSUserFiles/64080530/RUSLE/AH 537.pdf

[26] Environmental Systems Research Institute (ESRI) (2015) ArcGIS Desktop: Release 10.5.1. Redlands, CA. 
[27] Environmental Systems Research Institute (ESRI) (2004) ModelBuilder. https://desktop.arcgis.com/en/arcmap/10.5/analyze/modelbuilder/what-is-modelbui lder.htm

[28] U.S. Department of Agriculture (USDA) (2014) Geographic Information Data. Region 4 Forest Service, Ogden, UT.

[29] U.S. Geological Survey (USGS) (2013) USGS NED n41w111 1/3 Arc-Second 2013 1x1 Degree IMG. Raster Digital Data. Reston, VA. http://ned.usgs.gov

[30] U.S. Department of Agriculture (USDA) (2016) NAIP Digital Ortho Photo Image TIF. Remote Sensing Image. USDA-FSA-APFO Aerial Photography Field Office, Salt Lake City, UT.

https://www.fsa.usda.gov/programs-and-services/aerial-photography/imagery-prog rams/naip-imagery/index

[31] U.S. Fish and Wildlife Service (USFWS) (2016) National Wetlands Inventory CONUS_wet_poly_West. Shapefile. Washington DC. https://www.fws.gov/wetlands/

[32] U.S. Department of Agriculture (USDA) (2014) Maps and Data Files for Grazing Suitability-High Uintas Domestic Sheep Project Area. Region 4 Forest Service, Ogden, UT.

[33] U.S. Department of Agriculture (USDA) (2016) High Uinta Sheep Allotment Pastures. Shapefile. U.S. Forest Service Uinta-Wasatch-Cache Supervisor's Office, Salt Lake City, UT.

[34] U.S. Geological Survey (USGS) (2016) National Hydrography Dataset Water Bodies. Geodatabase Polygon Feature Class. USGS-National Geospatial Technical Operations Center (NGTOC), Rolla, MO and Denver, CO.

http://viewer.nationalmap.gov/

[35] U.S. Department of Agriculture (USDA) (2001) U.S. Forest Service. Ashley National Forest Cattle and Sheep Grazing Capability Layer. Shapefile.

[36] U.S. Department of Agriculture (USDA) (2001) U.S. Forest Service: Uinta-WasatchCache National Forests Cattle and Sheep Grazing Capability Layer. Shapefile. USDA Region 4 Forest Service, Ogden, UT.

[37] U.S. Department of Agriculture (USDA) (2011) Soils: High Uinta Sheep: Shapefile. Uinta Wasatch Cache National Forest. Salt Lake City, UT.

[38] U.S. Department of Agriculture (USDA) (2016) The Land Type Map of Component Vegetation, Soil, and Geology-Ashley National Forest. Shapefile. U.S. Forest Service Uinta-Wasatch-Cache Natural Resource Manager Office. Salt Lake City, UT.

[39] U.S. Department of Agriculture (USDA) (2014) Brief Soil Descriptions Wasatch-Cache National Forest. Region 4 Forest Service, Ogden, UT.

[40] Bureau of Land Management (BLM) (1996) Utilization Studies and Residual Measurements-Interagency Technical Reference 1734-03. BLM National Applied Resource Science Center, Denver, CO.

[41] U.S. Department of Agriculture (USDA) (2017) National Agricultural Statistics Service. Livestock Slaughter.

[42] Holechek, J.L., Pieper, R.D. and Herbel, C.H. (2004) Range Management Principles and Practices. 5th Edition, Prentice-Hall, Upper Saddle River, NJ.

[43] Cole, D.N. and Landres, P.B. (1996) Threats to Wilderness Ecosystems: Impacts and Research Needs. Ecological Applications, 6, 168-184.

https://doi.org/10.2307/2269562 
[44] Ruediger, B., Claar, J., Mighton, S., Naney, B., Rinaldi, T., Wahl, F., Warren, N., Wenger, D., Williamson, A., Lewis, L., Holt, B., Patton, G., Trick, J., Vandehey, A. and Gniadek, S. (2000) Canada Lynx Conservation Assessment and Strategy. USDA Forest Service, USDI Fish and Wildlife Service, USDI Bureau of Land Management, and USDI National Park Service. Forest Service Publication, Missoula, MT. https://digitalcommons.unl.edu/usfwspubs/197

[45] Toweill, D.E. and Geist, V. (1999) Return of Royalty-Wild Sheep of North America. Boone and Crocket Club, Foundation for North American Wild Sheep, Missoula, MT.

[46] Monello, R.J., Murray, D.L. and Cassirer, E.F. (2001) Ecological Correlates of Pneumonia Epizootics in Bighorn Sheep Herds. The Canadian Journal of Zoology, 79, 1423-1432. https://doi.org/10.1139/z01-103 